in a population of children who were largely immune, by vaccination, to type 1,2 and type 1,2,3 infection. Evidence is here presented (Table IV and accompanying text) to suggest that a further process of selection is occurring: type 1,3 strains isolated in 1963 were readily agglutinated by both antibodies (1 and 3); but during 1964 an increasing proportion were agglutinated very poorly by antibody 1 and appeared to have only one major agglutinogen (antigen 3 ). Thus organisms which produce antigens 1 and 2 as major components are apparently being eradicated by efficient vaccines in which these two antigens are well represented, while strains in which antigen 3 is the major component are able to flourish in the vaccinated community.

There is therefore an immediate need to modify the pertussis vaccines used in this country so that they contain strains in which all three antigens are adequately represented; and it is reasonable to believe that such modified vaccines would protect against pertussis infections caused by all three serotypes. It is important, however, that checks be made from time to time on the antigenic nature of strains isolated, especially from vaccinated persons, so that, if this modification of the vaccines should cause the emergence of yet another serotype as the predominant form of the organism, appropriate adjustments may be made in the strain-composition and testing of vaccines.

The present mode of assay, in testing the potency of pertussis vaccine, is clearly inadequate. Batches of vaccine which are rich in antigens 1 and 2 will readily pass the test, though they give children incomplete protection against current infecting strains. The need for a different form of potency test is discussed elsewhere (Preston, in press).

\section{Summary}

Eleven British pertussis vaccines and vaccine strains in current use have been examined serologically by slide- agglutination with monospecific pertussis antisera. All contained antigens 1 and 2, but antigen 3 was found in only one of them.

So effective are these vaccines that type 1,2 strains of Bordetella pertussis have been virtually eliminated in this country. Vaccination gives adequate protection also against type 1,2,3 strains, which in 1963-4 have been isolated only from unvaccinated patients. Type 1,3 strains, however, have infected both vaccinated and unvaccinated people, and have constituted $132(85 \%)$ of the 155 strains examined.

Of the type 1,3 strains isolated during 1964 an increasing proportion have been very poorly agglutinated by antibody 1 , though they were still agglutinated readily by antibody 3 . These strains constitute a new subtype against which vaccines containing only antigens 1 and 2 could not be expected to immunize.

There is an urgent need for the modification of pertussis vaccine so that it shall contain strains in which all three antigens are adequately represented.

This investigation was undertaken only with the ready co-operation of medical practitioners, scientific officers, and technicians, whose help and assistance are gratefully acknowledged-namely; Dr. J. W. Howie and the staff of the Public Health Laboratory Service; paediatricians and general practitioners in Manchester, Salford, and Wigan; the clinical and laboratory staff of the hospitals named in the text ; and the technical staff of this department.

\section{REFERENCES}

Andersen, E. K. (1953). Acta path. microbiol. scand., 33, 202 Preston, N. W. (1963). Brit. med. F., 2, 724 Preston, Path. Bact. In press.

and Te Punga, W. A. (1959). Ibid., 78, 209.

Report: Public Health Laboratory, Manchester; City of Manchester Health Department ; Department of Bacteriology, University of Manchester (1965). Mth. Bull. Minist. Hlth Lab. Serv., 24, 104.

\title{
Studies on Killed and Attenuated Measles Vaccines in General Practice
}

\author{
G. I. WATSON,* M.D., M.C.G.P.
}

Brit. med. F., 1965, 2, 13-16

The best way to prevent measles is still being sought. Attenuated measles virus vaccines, mainly derived from the Edmonston strain (Enders and Peebles, 1954), have been shown to confer substantial protection against the natural disease (Katz and Enders, 1959 ; Aldous et al., 1961 ; Katz et al., 1962; Goffe et al., 1963 ; Krugman et al., 1965), but these vaccines also produced varying degrees of fever and rash. Further attenuation of such vaccines has reduced but not yet abolished these adverse reactions (Schwarz, 1962 ; Hendrickse et al., 1964), and may diminish the antibody response (Benson et al., 1964). Meanwhile killed vaccines have been developed which evoke little or no adverse clinical reaction (Karelitz, 1963) but are less certain in their protection (Lipschutz et al., 1962).

A concurrent dose of gamma-globulin has been used to reduce or abolish the adverse clinical reactions to attenuated vaccines (Stokes et al., 1961), as well as in attempts to modify or prevent measles among contacts (Krugman et al., 1962). Fever and rash after attenuated vaccines have also been reduced by giving up to three doses of a killed vaccine at monthly intervals before live vaccine is injected (Karelitz and Peck, 1962 ; Guinee, 1963). This method has usually led to higher post-vaccination neutralizing antibody titres than when attenuated vaccine alone is given (Karelitz et al., 1963), but the reverse occurred in a recent trial among children aged 10-18 months (Measles Vaccines Committee, 1965).

Most studies on measles vaccines have been made in the United States. No report has been found dealing specifically with the influence of age on clinical and serological responses. A small number of serological results examined by Mr. G. J. Knight (personal communication, 1964) suggested that up to the age of 2 years "increasing age at vaccination is associated with an enhanced response to measles vaccination." No report has been published about the use in children over 2 years of killed vaccine for modifying adverse reactions to live attenuated vaccines made in Britain.

* General Practitioner, Peaslake, Surrey. 


\section{Present Study}

Vaccines Used.-In 1961 I was invited to study a batch of Eli Lilly's killed vaccine (No. 1260-P-69003). This was an aqueous suspension of aluminium-phosphate-adsorbed killed measles virus, derived from the Edmonston $B$ strain in chick-embryo-tissue culture. The dose used in each case was $1 \mathrm{ml}$. In 1962 an opportunity also arose to study the Wellcome Foundation live attenuated measles virus vaccine $M V-16$, and later MV-20. Each was derived originally by Goffe and Laurence (1961) from the Edmonston B strain and each had undergone a varying number of passages. In each case the freeze-dried vaccine was reconstituted in $1 \mathrm{ml}$. of diluting fluid.

Population.-Vaccines have been given to three adults, and to 69 children whose parents permitted blood samples to be taken before and after vaccination. All were attended in the normal course of general practice. Each dose of vaccine was injected and every reaction seen by me. No patient included in this report had a history of measles or of any contact with the disease. Before vaccination, in all those from whom blood samples were obtained, the neutralizing antibody titre was less than $1: 4$.

Antibody Titres.-The first serum sample was withdrawn either immediately before vaccination or a few days earlier. In each case the second sample was taken four weeks (or a few days later) after the dose of live vaccines. Two of those vaccinated with $\mathrm{MV}-16$ were later found to have raised pre-vaccination titres and have been excluded from this analysis. One of these cases has already been reported (Watson, 1963).

Virus-neutralizing antibody titres were determined in the pre- and post-vaccination sera from each patient in parallel tests by a method previously described (Goffe and Laurence, 1961), and were performed at the Wellcome Research Laboratories in Beckenham, Kent.

Records.-Each person was examined before vaccination. After killed vaccine the few reactions reported were seen and recorded as they occurred. A record was kept by the patient or parent for 14 days after a dose of live vaccine, when the presence or absence of malaise, loss of appetite, headache, disturbed sleep, evidence of respiratory infection, including rhinitis, cough, and sore throat, and of rash were recorded daily. The rectal or oral temperature was taken and recorded twice daily or more often during fever. Any positive reactions were seen daily by me. This report is based on detailed studies of 72 children and adults who were given killed or attenuated vaccines alone or in successive doses at varying intervals from three weeks to 18 months.

\section{Results}

\section{Killed Vaccine Alone}

Stability.-This killed vaccine has proved remarkably stable. It has been kept in 10-ml. rubber-capped bottles at room temperature in the dispensary since September 1961 and no change in its clinical or serological effects has been detected.

Clinical Reactions.-Forty-four subjects received one or more doses of killed vaccine. There were no serious adverse local or general vaccination reactions. Out of 62 doses 56 produced no local or general disturbance, three caused mild local erythema for one to three days, two produced sore arms for three days, and one was followed by fever to $101.8^{\circ} \mathrm{F}$. $\left(38.8^{\circ}\right.$ C.) for one day (Staphylococcus aureus rhinitis was also present in this child). Five out of six of these reactions occurred in three children of the same family.

Neutralizing Antibody Titres.-One adult and 11 children were vaccinated between September 1961 and March 1962. Of these, nine received three doses at monthly intervals and three had one dose each. Of the nine children who had three doses each, post-vaccination blood samples were obtained from seven: of these, four had samples taken one month after vaccination and all had a sample taken 12 to 14 months after their third dose. Of the three who had only one dose of vaccine, each had a post-vaccination sample taken after one month, and two also had blood taken 12 months later. The titres are shown in Table I.

TABLE I.-Neutralizing Antibody Titres after Killed Vaccine

\begin{tabular}{|c|c|c|c|}
\hline \multirow{2}{*}{$\begin{array}{c}\text { No. } \\
\text { Vaccinated }\end{array}$} & \multirow{2}{*}{$\begin{array}{l}\text { No. of } \\
\text { Doses }\end{array}$} & \multicolumn{2}{|c|}{ Titres } \\
\hline & & $\begin{array}{l}1 \text { Month After } \\
\text { Last Dose }\end{array}$ & $\begin{array}{l}\text { 12-14 Months } \\
\text { After Last Dose }\end{array}$ \\
\hline $\begin{array}{l}9 \\
3\end{array}$ & $\begin{array}{l}3 \\
1\end{array}$ & $\begin{array}{l}32,128,181,727 \\
<32,<4,6\end{array}$ & $\begin{array}{l}6,11,11,23,45,45,64 \\
<4,32\end{array}$ \\
\hline
\end{tabular}

\section{Live Attenuated Vaccines Alone}

Two live vaccines have been used, $M V-16$ and $M V-20$. Vaccination with MV-16 began in October 1962 and with MV-20 in October 1963. Vaccines have not been given during December to March any year except to measles contacts, so febrile reactions due to intercurrent infection have been uncommon. Nineteen people were given only MV-16. Of these, nine were not in contact with measles; seven, including one adult, were house contacts within three days of the onset of infection; and three had been in contact with measles for more than three days. The adult and four of the six children in early contact with measles, who developed only normal post-vaccination reactions but no respiratory symptoms within the incubation period of the natural disease (Watson, 1963), have been included in the analysis of those immunized with MV-16. Five contacts who developed morbilliform rashes or respiratory symptoms are discussed later. Nine children given MV-20 alone were not in contact with measles. A summary of the clinical reactions and disability after these vaccines is shown in Table II.

TABLE II.-Summary of Clinical Reactions and Disability after

\begin{tabular}{|c|c|c|c|c|c|c|c|c|c|}
\hline \multirow[b]{2}{*}{$\begin{array}{l}\text { Type of } \\
\text { Vaccine }\end{array}$} & \multirow[b]{2}{*}{ Total } & \multicolumn{3}{|c|}{ Fever Peak } & \multirow{2}{*}{$\begin{array}{l}\text { Rash } \\
\text { (Rose- } \\
\text { olar) }\end{array}$} & \multicolumn{3}{|c|}{ Bed Rest } & \multirow{2}{*}{$\begin{array}{l}\text { Missed } \\
\text { School } \\
1 \text { Day } \\
\text { or More }\end{array}$} \\
\hline & & None & $\begin{array}{c}\text { Under } \\
101^{\circ} \mathrm{F} . \\
\left(38 \cdot 3^{\circ} \mathrm{C} .\right)\end{array}$ & $\begin{array}{l}103^{\circ} \mathrm{F} . \\
\left(39 \cdot 4^{\circ} \mathrm{C} .\right) \\
\text { or Over }\end{array}$ & & None & \begin{tabular}{|c|} 
Part \\
Day \\
Only
\end{tabular} & $\mid \begin{array}{c}1-4 \\
\text { Days }\end{array}$ & \\
\hline MV-16 & 13 & 0 & 3 & 5 & 13 & 8 & 3 & 2 & 8 \\
\hline $\begin{array}{c}\text { MV-20 } \\
\text { only }\end{array}$ & 9 & 0 & 6 & 0 & 6 & 6 & 3 & 0 & 5 \\
\hline
\end{tabular}

Febrile Reactions.-Every person vaccinated with $\mathrm{MV}-16$ or $\mathrm{MV}-20$ showed a rise in temperature between the fifth and tenth days after vaccination $(\mathrm{V}+5$ to $\mathrm{V}+10)$. All those who received $\mathrm{MV}-16$ alone developed temperatures of $100^{\circ} \mathrm{F}$. $\left(37.8^{\circ} \mathrm{C}\right.$.) or over by $\mathrm{V}+8$ and were afebrile again by $\mathrm{V}+11$. There was a suggestion that the younger the child the earlier its fever began and the higher the peak. Those vaccinated with $\mathrm{MV}-20$ started fever on $\mathrm{V}+6$, reaching peaks ranging from $99-102.6^{\circ} \mathrm{F}$. (37.2-39.2 ${ }^{\circ} \mathrm{C}$.), and were afebrile by $\mathrm{V}+11$. Age appeared to influence not only the height of fever but also the antibody response to both $\mathrm{MV}-16$ and $\mathrm{MV}-20$ (see Table III). There were no other rises of temperature outside the period of vaccine reaction and no intercurrent infections.

Rash.-All those immunized with $\mathrm{MV}-16$ and six of the nine treated with $M V-20$ developed roseolar rashes on $V+9$, 10 , or 11 as their temperatures fell (Watson, 1965). No Koplik's spots appeared. The rash had faded by $\mathrm{V}+11$ to $\mathrm{V}+14$ (Table II).

General Reaction.-After MV-16 the general reaction, based on recorded symptoms and signs, was graded as "mild" in 11 and "marked" in two (sisters aged 4 and 6 years). After MV-20 it was graded as "none" in two, "very mild" in 
TABLE III.-Peak of Fever and Range of Serological Response in Children Given Attenuated Measles Virus Vaccines-by Age Groups

\begin{tabular}{|c|c|c|c|c|c|c|c|c|c|}
\hline \multicolumn{5}{|c|}{ MV-16 } & \multicolumn{5}{|c|}{ MV-20 } \\
\hline \multirow{2}{*}{ Age Group } & \multirow{2}{*}{ No. } & \multicolumn{2}{|c|}{ Peak of Fever } & \multirow{2}{*}{$\begin{array}{l}\text { Range of } \\
\text { Post-vacc. } \\
\text { Titres }\end{array}$} & \multirow{2}{*}{ Age Group } & \multirow{2}{*}{ No. } & \multicolumn{2}{|c|}{ Peak of Fever } & \multirow{2}{*}{$\begin{array}{c}\text { Range of } \\
\text { Post-vacc. } \\
\text { Titres } \\
\end{array}$} \\
\hline & & ${ }^{\circ} \mathbf{F}$. & ${ }^{\circ} \mathrm{C}$. & & & & ${ }^{\circ} \mathbf{F}$. & ${ }^{\circ} \mathrm{C}$. & \\
\hline $\begin{array}{l}1 \text { y. } 10-3 \text { y. } 10 \\
4 \text { y. } 5-6 \text { y. } 3 \\
7 \text { y. } 4-14 \text { y. } 2\end{array}$ & $\begin{array}{l}3 \\
5 \\
5\end{array}$ & $\begin{array}{l}102 \cdot 6-103 \cdot 4 \\
102 \cdot 6-105 \cdot 0 \\
100 \cdot 0-103.0\end{array}$ & $\begin{array}{l}39 \cdot 2-39 \cdot 7 \\
39 \cdot 2-40 \cdot 6 \\
37 \cdot 8-39 \cdot 4\end{array}$ & $\begin{array}{l}N / T-512 \\
64-727 \\
45-181\end{array}$ & $\begin{array}{l}2 \text { y. } 2-3 \text { y. } 3 \\
4 \text { y. } 4-6 \text { y. } 4 \\
8 \text { y. } 10-10 \text { y. } 9\end{array}$ & $\begin{array}{l}2 \\
4 \\
3\end{array}$ & $\begin{array}{l}99 \cdot 4-102 \cdot 4 \\
99 \cdot 0-102.6 \\
99 \cdot 6-100 \cdot 4\end{array}$ & $\begin{array}{l}37 \cdot 4-39 \cdot 1 \\
37 \cdot 2-39 \cdot 2 \\
37 \cdot 6-38 \cdot 0\end{array}$ & $\begin{array}{l}\mathrm{N} / \mathrm{T}-362 \\
90-362 \\
23-181\end{array}$ \\
\hline
\end{tabular}

three, and "mild" in four. Eight out of the 13 children immunized with MV-16 and six out of nine with MV-20 did not need to rest in bed. After MV-16 two children needed more than one whole day in bed. No respiratory symptoms were caused by either of the vaccines (Table II).

School Attendance.-Eight out of 13 children immunized with $M V-16$ and five treated with $M V-20$ missed one or more days at school ; but after MV-20 no child missed more than one whole day (Table II).

Antibody Response.-All those who received live vaccines alone developed an antibody response. The antibody titres after $M V-16$ and $M V-20$ were similar to those reported after other attenuated vaccines. Knight (personal communication) could show no significant difference between the mean antibody titres after $M V-14$, an earlier vaccine, and $M V-16$; but in this study, age for age, most of the titres after MV-20 were slightly lower than those after MV-16 (see Table IV); larger numbers would be required to assess this trend. With both vaccines antibody levels tended to be higher in children under 7 years of age, and were lower in older children.

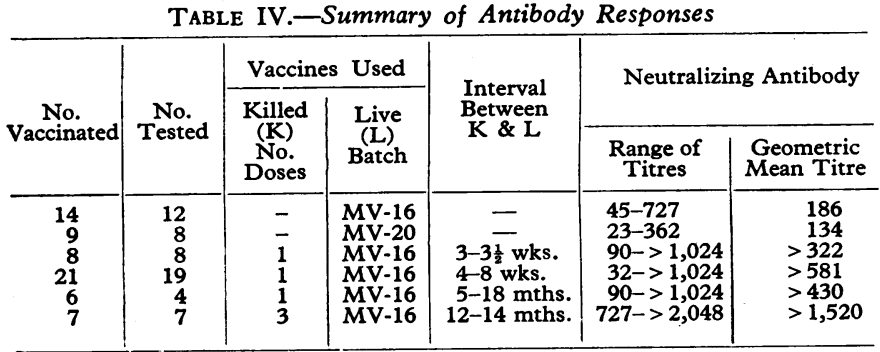

\section{Killed Followed by Live Vaccine}

Forty-two people (including two adults) out of the 44 who had received either one or three doses of killed vaccine have since been challenged with attenuated measles vaccine $M V-16$ after intervals varying from three weeks to 18 months; two children who had reactions after being given three doses of killed vaccine in 1961-2 have not been revaccinated. A summary of the clinical reactions after this combined schedule is shown in Table V.

Febrile Reactions.-Either one dose or three doses of killed vaccine given three weeks or more before the dose of live attenuated vaccine greatly reduced the febrile reaction normally present when MV-16 was given alone. $100.6^{\circ} \mathrm{F}$. $\left(38.1^{\circ}\right.$ C. $)$ was the highest oral temperature, probably due to the vaccine, recorded during the reaction phase between $\mathrm{V}+5$ and $\mathrm{V}+10$; one child had a temperature of $102^{\circ} \mathrm{F} .\left(38.9^{\circ} \mathrm{C}\right.$.) on $\mathrm{V}+5$ after severe insect bites but no subsequent fever, and another had a rise to $101.3^{\circ} \mathrm{F}$. $\left(38.5^{\circ} \mathrm{C}\right.$.) on $\mathrm{V}+6$ with acute otitis media.

Rises of temperature associated with intercurrent infections occurred in a few children outside the normal period of vaccine reaction as follows : 100 and $100.4^{\circ} \mathrm{F}$. (37.8 and $39^{\circ}$ C.) on $\mathrm{V}+4,100.6^{\circ} \mathrm{F}$. $\left(39.1^{\circ}\right.$ C.) on $\mathrm{V}+11,100,100.1$, and $101.0^{\circ}$ F. $\left(37.8,37.8\right.$, and $38.3^{\circ}$ C.) on $V+12$, and $103.8^{\circ}$ F. $\left(39.9^{\circ}\right.$ C.) on $\mathrm{V}+13$ due to Bornholm disease (Coxsackie $\mathrm{B}_{1}$ virus isolated).

General Reactions.-No child who received one or more doses of killed vaccine prior to the live vaccine suffered any malaise or respiratory symptoms, or needed to rest in bed; and none developed a rash.

School Attendance.-No child given killed vaccine three weeks or more before the live vaccine missed any time from school.

Interval between Doses.-Three doses of killed vaccine gave no better clinical results than one dose; nor did an interval of three weeks between a single dose of killed and live vaccine give less clinical benefit than longer intervals varying from four weeks to 18 months.

Antibody Response.-The titre of neutralizing antibody in children who had received one dose of killed vaccine three weeks or more before their live vaccine was in nearly every case higher, age for age, than in those who were given $\mathrm{MV}-16$ or MV-20 alone. Children who had received three doses of killed vaccine about a year before their live vaccine showed still higher titres (see Table IV).

\section{Vaccination of House Contacts}

On or after the third day of exposure to fever or cough in the primary case nine children and one adult in contact with measles at home were vaccinated with $\mathrm{MV}-16$ alone. None had a history of previous measles and in each case the pre-vaccination titre of neutralizing antibody was negative at $1: 4$. In the adult and four of the children the normal vaccination reaction (fever without respiratory symptoms followed by roseolar rash) appeared within the incubation period of the natural disease. In two children vaccinated on the third (possibly fourth) day after contact with the primary case $(\mathrm{C}+3$ or $\mathrm{C}+4)$ no respiratory symptoms developed but there were morbilliform elements to the rash; faint staining occurred in both, and one had a few Koplik-like lesions in the mouth. In two other children vaccinated on $\mathrm{C}+4$ or $\mathrm{C}+5$ a short modified attack of measles with respiratory symptoms was seen; and one youth vaccinated on $\mathrm{C}+5$ developed an attack of typical measles of average severity.

Table V.-Summary of Clinical Reactions After Combined Schedule; Killed Vaccine Given at Varying Intervals Prior to Live Attenuated Vaccine MV-16

\begin{tabular}{|c|c|c|c|c|c|c|c|c|c|}
\hline \multirow{4}{*}{$\begin{array}{c}\text { No. } \\
\text { Vaccinated }\end{array}$} & \multirow{4}{*}{$\begin{array}{c}\text { Killed } \\
\text { Vaccine } \\
\text { No. Doses }\end{array}$} & \multirow{4}{*}{$\begin{array}{c}\text { Interval } \\
\text { Before } \\
\text { Live } \\
\text { Vaccine }\end{array}$} & \multicolumn{7}{|c|}{ Between $V+5$ and $V+10$} \\
\hline & & & \multicolumn{4}{|c|}{ Peak Oral Temperature } & \multirow{3}{*}{ Rash } & \multirow{3}{*}{ Bed-rest } & \multirow{3}{*}{ Missed School } \\
\hline & & & \multicolumn{2}{|c|}{ Range } & \multicolumn{2}{|c|}{ Mean } & & & \\
\hline & & & ${ }^{\circ} \mathrm{F}$. & ${ }^{\circ} \mathrm{C}$. & ${ }^{\circ} \mathbf{F}$. & ${ }^{\circ} \mathrm{C}$. & & & \\
\hline $\begin{array}{r}8 \\
21 \\
6 \\
7\end{array}$ & $\begin{array}{l}1 \\
1 \\
1 \\
3\end{array}$ & $\begin{array}{l}3-3 \frac{1}{2} \text { wks. } \\
4-8 \text { wks. } \\
5-18 \text { mths. } \\
\text { 8-14 mths. }\end{array}$ & $\begin{array}{l}98 \cdot 0-99 \cdot 4 \\
98 \cdot 2-100 \cdot 6 \\
98 \cdot 0-100 \cdot 2 \\
98 \cdot 4-99 \cdot 2\end{array}$ & $\begin{array}{l}36 \cdot 7-37 \cdot 4 \\
36 \cdot 8-38 \cdot 1 \\
36 \cdot 7-37 \cdot 9 \\
36 \cdot 9-37 \cdot 3\end{array}$ & $\begin{array}{l}98 \cdot 7 \\
98 \cdot 8 \\
98 \cdot 6 \\
98 \cdot 9\end{array}$ & $\begin{array}{l}37 \cdot 1 \\
37 \cdot 1 \\
37 \cdot 0 \\
37 \cdot 2\end{array}$ & $\begin{array}{l}0 \\
0 \\
0 \\
0\end{array}$ & $\begin{array}{l}0 \\
0 \\
0 \\
0\end{array}$ & $\begin{array}{l}0 \\
0 \\
0 \\
0\end{array}$ \\
\hline
\end{tabular}




\section{Discussion}

Immunization against measles has two objectives. The first, to immunize against the disease without vaccination reactions sufficient to hinder normal activity or schooling. The second, to produce an immunity lasting as long as that which follows natural infection.

Neither of the two attenuated vaccines-Wellcome MV-16 or MV-20-when used alone achieved the first objective. The antibody response to each of these vaccines was satisfactory; though a larger series matched by age would be needed to confirm the suggestion, noted also by Benson et al. (1964), that titres after MV-20 were slightly lower than those after MV-16.

A combined schedule, in which one dose of killed vaccine was given three or more weeks before attenuated vaccine, appeared to achieve both objectives. There was virtually no adverse clinical reaction after either dose of vaccine in 42 consecutive patients; and the mean antibody response in those over the age of 3 years was better than that after either of the attenuated vaccines-MV-16 or MV-20-alone. Reducing the interval between vaccines to three weeks rather than to four to eight weeks did not appreciably reduce the antibody response. When three doses of killed vaccine had preceded the dose of attenuated vaccine the mean antibody titre was considerably higher-better, indeed, than the titre in patients convalescent from an attack of natural measles. In this series there were insufficient children aged less than 3 years to determine the response in younger children; but when the results are combined with data provided by the Wellcome Foundation from other comparable studies the evidence suggests that the antibody responses to attenuated measles-virus vaccines $M V-14, M V-16$, and $M V-20$ used alone have increased exponentially with age from less than eight months up to over two years.

There was a suggestion that both the clinical reaction and the antibody response to attenuated vaccine alone in children aged between 6 and 14 years diminished with increasing age. This may only have been a result of using the same dose of vaccine in children of varying body weight. It does, however, point to the need for studying the influence of age in young children and also on dosage in older children and adults.

The findings indicate that vaccination of home and school contacts of measles with the present live attenuated vaccines may protect if treatment can be given promptly. The degree of protection appeared to depend on the duration of symptoms, particularly cough, in the primary case. Even if the primary case had developed his rash, if he had not been coughing or sneezing for more than three days, vaccination of contacts with MV-16 appeared to prevent or modify the natural disease.

Many parents are interested in the vaccination of their children against measles. The disease is mainly spread in school, at parties, or in places of entertainment. Apart from invalids, the children who particularly need protection are those engaged in these activities. If this age group is adequately vaccinated the chance of measles reaching children aged 2 years or less will be greatly reduced. However, if mass vaccination is concentrated on the pre-school and younger schoolchildren vaccine reactions may be expected to be maximal for any given batch of live vaccine, unless a preceding dose of killed vaccine has been given. With so much public good will at stake from successful immunization programmes in the past, it would be unfortunate if adverse clinical reactions in even a small proportion of those vaccinated with attenuated virus alone were to earn measles vaccination a bad public image. This applies particularly to the first year of mass vaccination. Family doctors up and down the country, who would be called upon to attend such children with febrile reactions, will recognize at once the validity of this argument.
To conclude, a combined schedule of killed vaccine followed in three to six weeks by live attenuated vaccine would appear to be highly satisfactory for immunizing children aged 3 years and over, and could be achieved with present vaccines. It is not yet established whether vaccination in children aged 2 years or less will give as prolonged protection against natural measles as in older children; nor whether further attenuation of live vaccines will improve or diminish the antibody responses.

\section{Summary}

Detailed studies have been made on 69 children and three adults who were treated with killed or live attenuated measlesvirus vaccines alone or in successive doses at intervals varying from three weeks to 18 months.

The vaccines used were two British live attenuated strainsWellcome MV-16 and MV-20-and Eli Lilly's aluminiumphosphate-adsorbed killed vaccine. The latter has been stable at room temperature for over three years.

Clinical and serological reactions to live vaccines appear to vary with age, being maximal in children aged about 3-6 years. Diminishing reactions in older children may be related to dosage.

One dose of killed vaccine, given three or more weeks before live vaccine, abolished the adverse clinical reactions but enhanced the antibody response in children over the age of 3 years.

Rapid immunization of measles contacts with live attenuated vaccines is possible up to the third evening after contact with symptoms in the primary case.

I am glad to acknowledge the help and encouragement in planning these studies which I received from Dr. T. M. Pollock, Director of the Epidemiological Research Laboratory, Colindale; and Dr. A. P. Goffe and Miss G. D. Laurence, of the Wellcome Research Laboratories. I am grateful to Dr. P. D. Kurtz, Dr. F. Latham, and Mr. E. A. G. Cook, of Eli Lilly and Co. Ltd., who first introduced me to measles vaccine; to Miss Laurence again, particularly, for her generous help in carrying out all these additional antibody titrations during the last three years; to Mr. G. J. Knight, of the Wellcome Research Laboratories, for his interest and statistical advice; to the Wellcome Foundation for supplies of vaccine and for a grant to cover expenses; and to the Medical Research Council for a personal grant held during this period.

\section{REFERENCES}

Aldous, I. R., Kirman, B. H., Butler, N., Goffe, A. P., Laurence, G. D., and Pollock, T. M. (1961). Brit. med. F., 2, 1250 . Benson, P. F., Butler, N. R., Goffe, A. P., Knight, G. J., Laurence,

Enders, J. F., and Peebles, T. C. (1954). Proc. Soc. exp. Biol. (N.Y.), 86, 277.

Goffe, A. P., and Laurence, G. D. (1961). Brit. med. f., 2, 1244. Woodall, J. T., Tuckman, E., Paulett, J. D., Manser, I. N., Franklin, L. M., and Chapple, P.A. L. (1963). Ibid., 1, 26.

Guinee, V. F. (1963). Amer. F. publ. Hlth, 53, 645.

Hendrickse, R. G., Montefiore, D., Sherman, P. M., and van der Wall, H. M. (1964). Brit. med. F., 1, 470.

Karelitz, S. (1963). N.Y. St. F. Med., 63, 519.

Berliner, B. C., Orange, M., Penbharkkul, S., Ramos, A., and Muenboon, P. (1963). F. Amer. med. Ass., 184, 673.

- and Peck, F. B., jun. (1962). Amer. F. Dis. Child., 103, 427.

Katz, S. L., and Enders, J. F. (1959). Ibid., 98, 605.

Krugman, S., Giles, J. P., Friedman, H., and Stone, S. (1965). F. Pediat. 66, 471 .

Jacobs, A. M., and Friedman, H. (1962). Amer. F. Dis. Child., 103, 353.

Lipschutz, A., Karpinski, F. E., jun., Shaw, E. B., Kempe, C. H., Peck, F. B., jun., and Feldman, H. A. (1962). Ibid., 103, 429.

Measles Vaccination Committee (1965). Brit. med. F., 1, 817

Schwarz, A. J. F. (1962). Amer. F. Dis. Child., 103, 386.

Stokes, J., Hilleman, M. R., Weibel, R. E., Buynak, E. B., Halenda, R. and Goldner, H. (1961). New Engl. 尹. Med., 265, 507.

Watson, G. I. (1963). Brit. med. F., 1, 860.

(1965). F. Coll. gen. Practit. In press. 